Please quote as: Bitzer, P.; Lehmann, K. \& Leimeister, J. M. (2012): A Literature Review on the Indicators for the Measurement of Technology Mediated Learning Productivity. In: Proceedings of the Eighteenth Americas Conference on Information Systems (AMCIS), Seattle, Washington, USA. 


\title{
A Literature Review on the Indicators for the Measurement of Technology Mediated Learning Productivity
}

\author{
Philipp Bitzer \\ Kassel University \\ bitzer@uni-kassel.de
}

\author{
Katja Lehmann \\ Kassel University \\ katja.lehmann@uni-kassel.de
}

\author{
Jan Marco Leimeister \\ Kassel University \\ leimeister@uni-kassel.de
}

\begin{abstract}
Measuring Technology Mediated Learning (TML) success has been and is of great interest to both researchers and practitioners. This article examines multidimensional approaches to measuring learning success, considering IT- and non-ITsupported learning scenarios, examined by researchers from various research disciplines. We explore the current state of research on TML success through a literature review by classifying empirically-oriented articles that were published between 2000 and 2011. Based on a total of 91 articles published in academic journal publications, this paper identifies the relevant research carried out, categorizes and consolidates the research results, and discusses them. The results show that those approaches are most dominant which empirically analyze the impact of a certain type of educational service on a student / participant by means of surveys and structural equation modeling to capture users' responses. No main theoretical basis of the reviewed studies could be identified. Furthermore, opportunities for additional development are identified and future research directions suggested.
\end{abstract}

\section{Keywords}

Technology-Mediated Learning, Productivity, Literature Review

\section{INTRODUCTION}

The market for corporate educational services in Germany in 2008 had a turnover of 26.5 billion euro (BMWI 2008). Overall, Arthur et al. (2003) identified the influence of technology in all learning scenarios referred to as technology-mediated learning (TML) as a major trend in vocational training. Basically, there is a consensus in theory and practice that advances in technology are the main agents of a dramatic change in the way people learn and students interact with their teachers (Chou 2003; DiMaggio et al. 2001; Joiner 2004; Rossett 2002). Technology-mediated learning scenarios will gain more importance and will lead to new ways of learning, e.g. micro-learning at the workplace or location-independent cloud-based learning (MBB 2011).

Research on TML has drawn from many fields in addition to information systems. Psychology, education, organizational behavior and computer science have contributed directly or indirectly to the topic (Gupta et al. 2008). From a business perspective, it can be shown that since the use of educational information technology is on the rise, an increase in productivity creates economically relevant potentials (Strother 2002). Unfortunately, there is no unified notion of productivity in the services sector (Leimeister 2012), which results in an inconclusive database for the impact of TML services on an individual and team level. Many studies have used input-output research designs that neglect critical aspects of the learning method and process (Gupta et al. 2009). The research done so far is not adequate to face the upcoming challenges in TML and still is not sufficient for the dynamic development in practice (Alavi et al. 2001; Sasidharan et al. 2006). Consequently, a systematic approach is necessary to integrate and evaluate technology in the field of TML which supports a productive service provision in terms of providers' input and the providers' and customers' respective output. 
Therefore, a common understanding of TML has to be created, considering results from various disciplines. Based on these results, researchers and training providers need to identify and analyze critical success factors for a productive TML provision considering multi-dimensional determinants and success factors.

The purpose of this article is to present and classify the current state of research on the measurement of TML success. More concretely, the following questions are addressed:

- Which approaches for assessing TML success can be found in the disciplines mentioned above?

- Which research designs were applied in past studies?

- What were the objects of analysis evaluated in this research?

In order to answer these questions, literature published between 2000 and 2011 was analyzed by means of a structured literature review. The review attempted to systematically analyze, categorize and synthesize a specific pool of peer-reviewed journal papers to provide a comprehensive overview of prior research in this area. According to Webster and Watson (2002), an effective literature review creates a firm foundation for advancing knowledge, eliminates areas where there is a plethora of literature, and uncovers fields where research is needed. This article tries to provide such an effective review and, thus, a theoretical basis for future research. The findings of this paper could be especially relevant to researchers who are new to this field and wish to obtain an overview of the topic, as well as insights into the latest published works.

\section{FOUNDATIONS}

Technology-mediated learning has many variations and is often a combination of the following learning modes: (blended learning): web-based or computer-based, asynchronous or synchronous, instructor-led or self-paced, individual or team-based (Gupta et al. 2009). More precisely, the goal of blended learning is to integrate the strengths of synchronous (face-to-face) and asynchronous (text-based internet) learning activities (Garrison et al. 2004). The great variety of research approaches and findings leads to inconclusive research results, due to different research foci in different disciplines against the backdrop of changing environmental circumstances.

Gupta and Bostrom (2009) developed a comprehensive theoretical model for the purpose of bridging the gap left by divergent results and increasing the accessibility for researchers and practitioners. They maintain that most research designs neglect critical aspects of the learning method and process (Alavi et al. 2001; Gupta et al. 2009). Hence, they developed a model which takes into account the learning context (spirit, i.e. learning goals and epistemological perspectives), learning method structures (structural impact), and the learning process (process impact). With these dimensions as its foundations, a productivity concept was identified and extended, based on the results of Bitzer et al. (2010): 


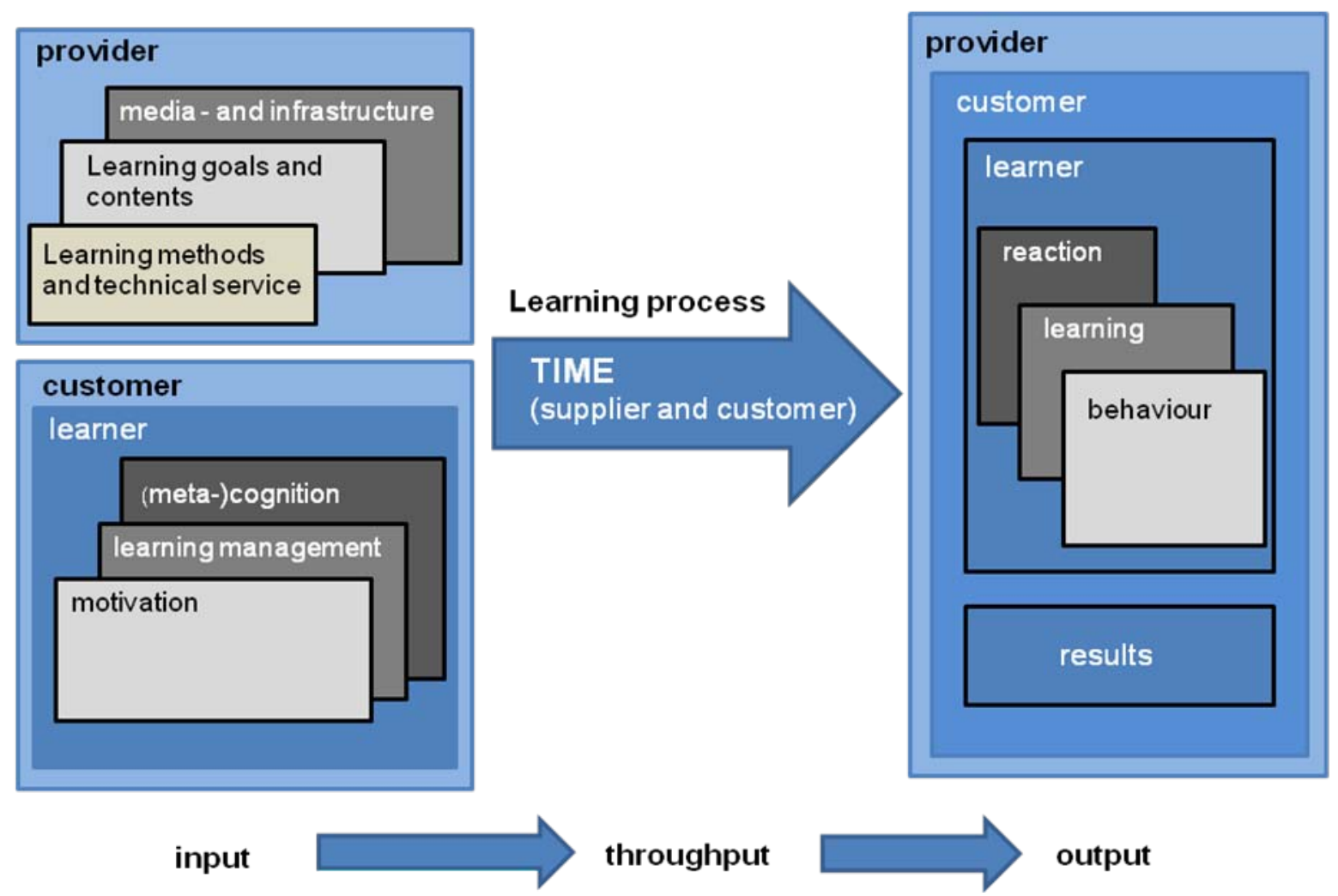

Based on the IS Model by DeLone and McLean (2003), the productivity concept by Grönroos (2004) and the learning success theory by Kirkpatrick (Kirkpatrick et al. 2005), the authors developed a conceptual productivity framework which comprised relevant factors, considering IS, business and education research (Bitzer et al. 2011). The framework was developed based on a literature review and an expert workshop.

From the supplier perspective, the following input factors are considered:

1.) Media and infrastructure (system quality): Technical or infrastructural inputs which are supplied by the provider in order to convey information to the customer.

2.) Learning goals and contents (information quality): Content of the training and the didactic underpinning, e.g. didactic models. This refers not only to the information to be conveyed but also includes the choice of editing of content for different types of media, and the integration and coordination of different learning channels.

3.) Learning method and technical services (service quality): Gupta and Bostrom (2009) maintain that the learning method can be considered an important determinant of learning success. It comprises the composition of the team, the adequateness of IT in supporting communication and structuring processes, and the instructor's teaching methods.

From the customer perspective the following input factors are considered:

1) Metacognition: Ability to plan, supervise, and adapt one's own cognition.

2) Cognition: Ability to learn, remember, and understand.

3) Management and control of own efforts: Ability to maintain learning effort in adverse environments (interruptions during training, difficult conditions.

4) Motivation: Willingness to put into action one's own strategies and capabilities.

The output perspective comprises the following dimensions:

1.) Reaction: Degree to which the desired reaction to the training is achieved.

2.) Learning: Skills acquired, attitudes, and knowledge imparted.

3.) Application of knowledge: Transfer of knowledge into work life.

4.) Business success: Degree to which the outcome of a training impacts organizational strategy on a global level 


\section{METHODOLOGY}

\section{Literature Review}

On account of the rising pile of literature, it becomes mandatory to conduct a thorough and systematic analysis of previously published texts in order to gain a general view on the current state of research on a specific topic (Fettke 2006). Therefore, a new contribution to the field should describe, summarize, explicate, and integrate the findings of selected primary works on the topic (2006). For the sake of quality assurance, we focused on literature which was not confined to one research methodology, one set of journals, or one geographic region, as recommended by Webster and Watson (2002).

\section{Literature Selection Process}

\section{Source Selection Process}

The disciplines considered in the course of the analysis of primary literature were education, information systems (use of technology), psychology (acquisition and implementation of knowledge), and management (contribution to turnover by educational services). The following five databases were used: Ebsco, ScienceDirect, IEEE Xplore, AIS Digital Library, ERIC and ISI. These sources were chosen because they cover the relevant disciplines and are said to be commensurate to academic purposes.

\section{Selection of papers}

We researched contributions published between 2000 and 2011, considering both IT- and non-IT-supported studies, to adequately address the blended (mixture between traditional and e-learning) character of TML and to collect results and research approaches from other disciplines such as education, psychology and business. Search terms were:

- $\quad$ efficiency OR effectiveness OR evaluation OR controlling OR measure AND

- learning OR teaching OR training OR education AND

- $\quad$ success OR achievement

Additionally, NOT operators were used, depending on the nature of the database. Terms like "medical," "public," "military," and "school" were excluded. On the whole, 3004 articles could be identified as relevant for analysis. The search results were screened between September 10th, 2011, and September 15th, 2011.

The articles and abstracts which appeared among the search results were taken down and highlighted if they corresponded with the goal of the study. Subsequently, the articles were read, and further relevant literature was identified. Finally, all selected articles were studied in order to find out about authentic output factors and factors of influence. This resulted in a body of works which were (1) peer reviewed journals, (2) exclusively concerned with adult education, and (3) whose aim was the measurement of the goal attainment of corporate educational services.

\section{RESULTS}

After a first double-checked screening of titles and abstracts in respect of the article's objective, 158 items remained for further scrutiny. 61 articles were subsequently considered "not relevant." Considering the focus of this study is on a comprehensive review of learning success on a micro-level, articles examining success on a macro-level were excluded. Furthermore, only those publications were considered which met scientific requirements (e.g. no journalistic articles). Consequently, a total amount of 91 articles was considered. Table1 gives a list of the selected journals.

\begin{tabular}{|l|}
\hline Literature Sources \\
\hline Education \\
\hline $\begin{array}{l}\text { Journal on Management Education (4x), Learning and Instruction (3x), Teaching and Teacher Education (3x), Decision } \\
\text { Sciences Journal on Innovative Education (2x), Applied Environmental Education and Communication, International } \\
\text { Journal of Leadership in Education, International Journal of Training and Development, Journal of Computer Assisted } \\
\text { Learning, Journal of Economic Education, Journal of Education for Business, Journal of European Industrial Training, } \\
\text { Journal of Marketing Education, Journal of Teaching in Social Work, Management Learning, Research in Middle Level } \\
\text { Education Online, Studies in Continuing Education, Teaching Sociology }\end{array}$ \\
\hline Psychology \\
\hline Journal of Personal Psychology (2x), Current Psychology, Cyber Psychology \& Behavior, Journal of Managerial \\
\hline
\end{tabular}




\begin{tabular}{|l||}
\hline Psychology \\
\hline Business / Economy \\
\hline $\begin{array}{l}\text { The Journal of American Academy of Business (3x), Business Communication Quarterly (2x), The International Journal } \\
\text { of Human Resource Management (2x), Academy of Management Learning \& Education, AEA Papers and Proceeding, } \\
\text { Atlantic Economic Journal, Bulletin of Economic Research, Bulletin of Economic Research, Department of Management } \\
\text { and Management Science, Human Resource Development International, Human Resource Management Journal, Institute } \\
\text { of Behavioral and Applied Management, International Journal of Industrial Ergonomics, International Journal of } \\
\text { Management, International Journal of Project Management, Issues in Accounting Education, Journal of Computer } \\
\text { Information Systems, Journal of Labor Economics, Journal of Political Economy, Total Quality Management, The } \\
\text { Review of Economics and Statistics, Organization Science, }\end{array}$ \\
\hline Information Systems \\
\hline $\begin{array}{l}\text { Computers and Education (12x), Transactions on learning technologies (7x), Computers in Human Behavior (3x), IEEE } \\
\text { Transactions on Education (2x), Information \& Management (2x), Internet and Higher Education (2x), British Journal of } \\
\text { Educational Technology, Food Service Technology, Information Systems Research, International Journal of an Emerging } \\
\text { Transdiscipline, International Journal of Human-Computer Interaction, Journal of Librarianship and Information Science, } \\
\text { Journal of Research on Technology in Education, MIS Quarterly, Transactions on Software Engineering }\end{array}$ \\
\hline
\end{tabular}

Table 1: Literature Sources

\section{Review Framework}

An analytical framework was defined to classify and describe the selected literature systematically. The framework is pictured below. 


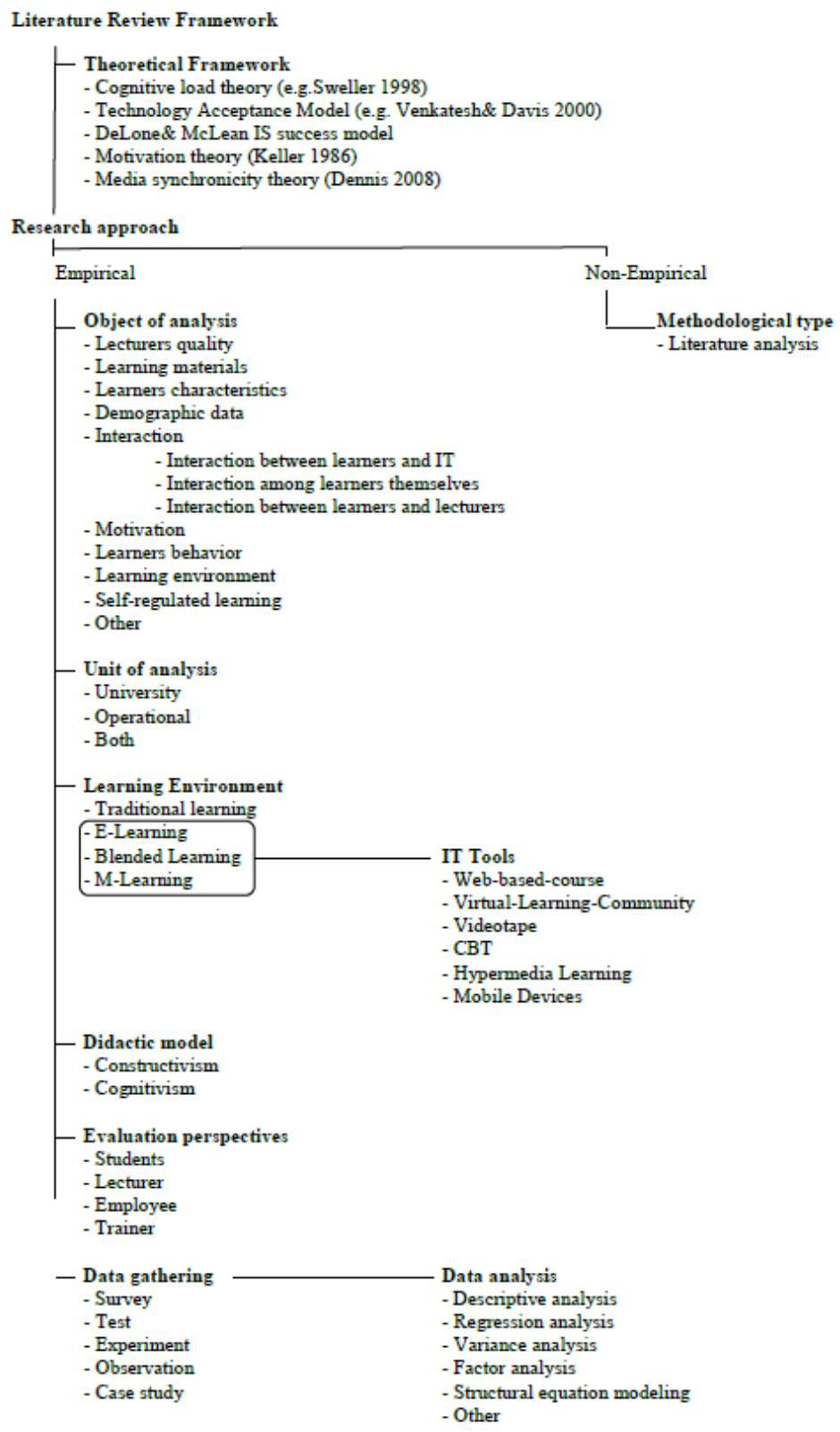

Figure 1: Literature Review Framework

\section{RESULTS}

The 91 selected journal articles were analyzed in respect of various dimensions. The results indicate that most of the papers do not refer to any specific theoretical foundation; in fact most of the articles cited similar studies in their related works section or did not reference any theoretical foundation. Furthermore, the objects of analysis varied strongly, most commonly focusing on quality of lecturers, characteristics of learners and interaction influence. Interestingly, most articles did not refer to any didactic model, only 25 could be identified which referred explicitly to a didactic theory. The evaluation perspective mostly focused on students. Most of the research we found came from a university background, only fourteen papers were examinations of learning services in a corporate context. Less than one third of the papers analyzed traditional learning scenarios. Blended or e-learning scenarios were the common focus of the studies. 


\section{Analysis of the Papers}
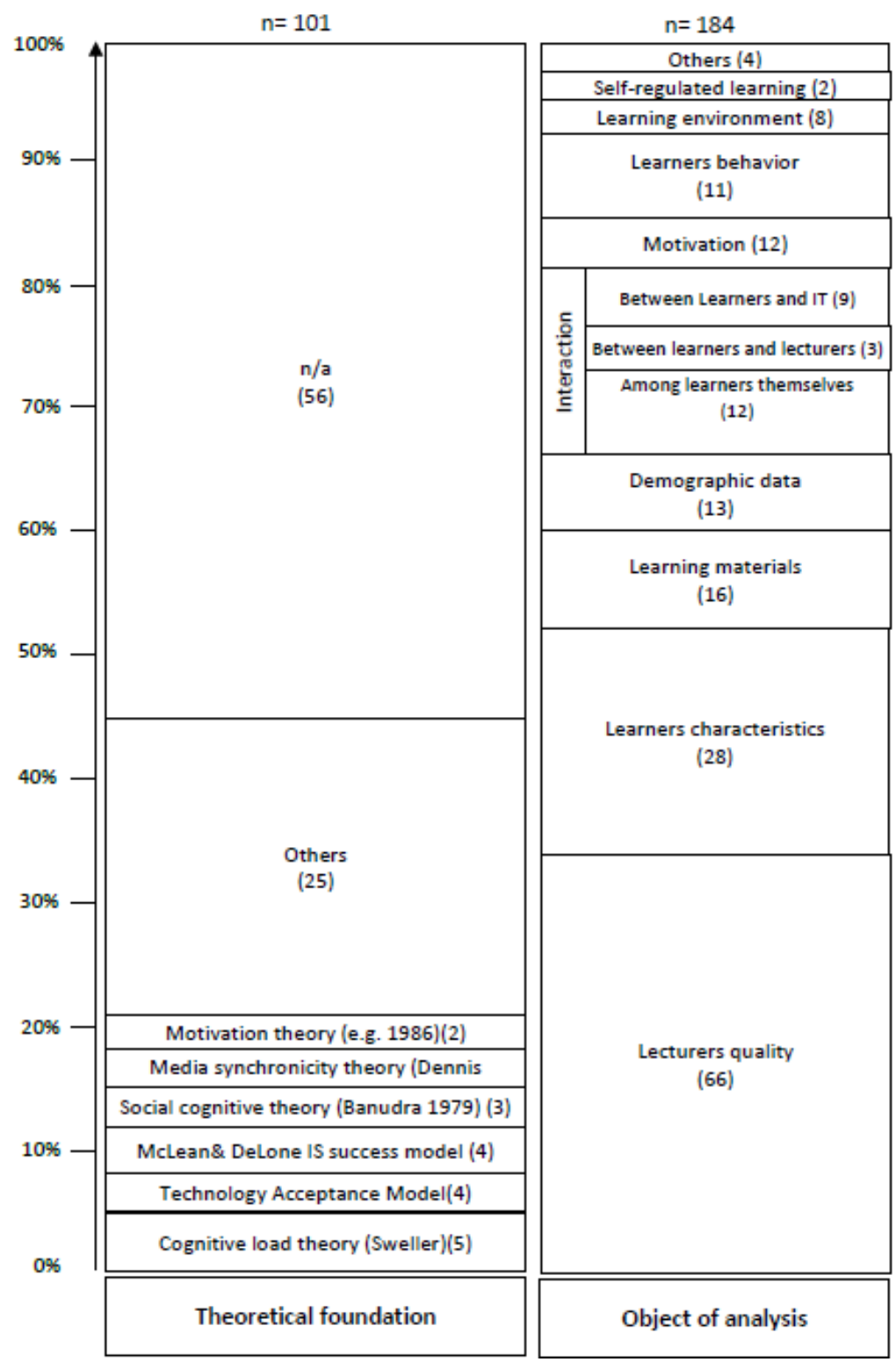

$n=96$

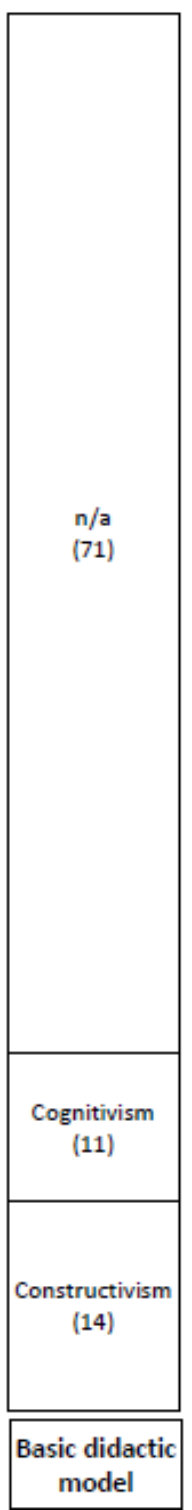

$\mathrm{n}=96$

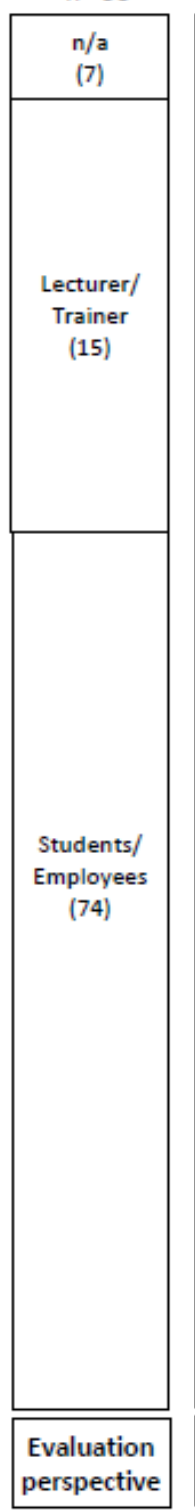

$n=94$

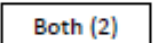

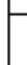
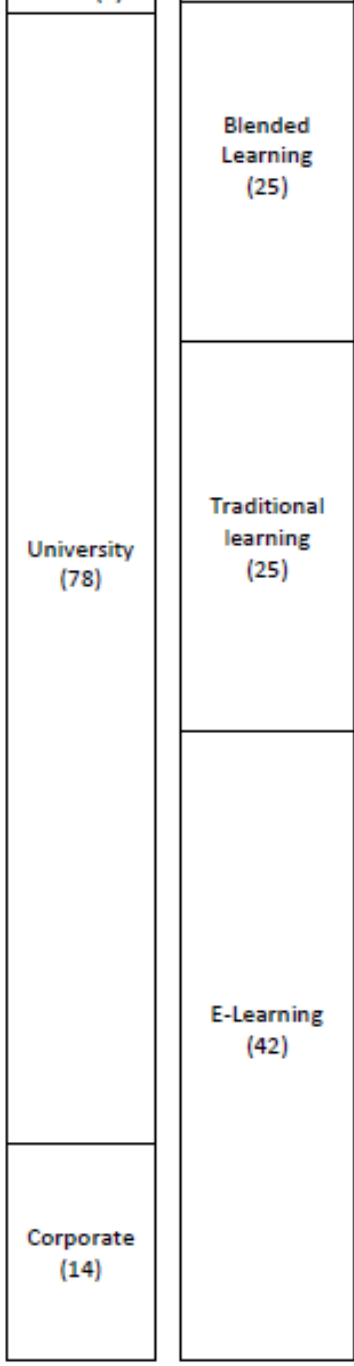

Unit of analysis
Learnin

(25)

$\mathrm{n}=93$

M-Learning (1)

Traditional

learning

(25)

E-Learning

(42)

Figure 2: Classification of Publications (Note: multiple allocations possible within one category) 


\section{IT -Objects of Analysis}

We investigated the IT -objects which were examined in the identified studies. The identified IT -tools were web-based courses, i.e. courses which were broadcasted via internet technologies with IT-supported interaction with the lecturer or learning software, virtual- learning- communities, i.e. web-based communities which support the interaction not only between students and lecturers but also between students. Moreover, several studies on videostreaming, on computer-based training and on mobile learning were identified. The results of the classification of the IT-tools are presented in Table 2

\begin{tabular}{|c|c|c|}
\hline \multicolumn{2}{|l|}{ IT Tools } & Publication \\
\hline \multirow[t]{3}{*}{ E-Learning (36) } & Web-based- course (23) & $\begin{array}{l}\text { (Aggarwal et al. 2006; Aleahmad et al. } \\
\text { 2009; Arbaugh 2000a; Arbaugh et al. } \\
\text { 2002; Arbaugh et al. 2007; Arbaugh 2001; } \\
\text { Austin 2009; Benbunan-Fich et al. 2006; } \\
\text { Bolliger et al. 2010; Bower et al. 2010; } \\
\text { Cheng et al. 2009; Friday et al. 2006; } \\
\text { Hansen 2008; Hornik et al. 2008; Johnson } \\
\text { et al. 2009; Lemak et al. 2005; Lin 2007; } \\
\text { Marks et al. 2005; Williams et al. 2006); } \\
\text { (Baker 2004; Jui-Feng et al. 2010; Li et al. } \\
\text { 2011; Sousa et al. 2010) }\end{array}$ \\
\hline & $\begin{array}{l}\text { Virtual-Learning-Community } \\
\text { (12) }\end{array}$ & $\begin{array}{l}\text { (Appleton 2010; Arbaugh 2000b; Arbaugh } \\
\text { 2000c; Edmonds et al. 2008; Graham } \\
\text { 2007; Hui et al. 2008; Nabil 2009; Ozkan } \\
\text { et al. 2009; Piccoli et al. 2001; Qiyun } \\
\text { 2010; Salleh et al. 2011; Tao et al. 2001) }\end{array}$ \\
\hline & Videostreaming (1) & (Zhang et al. 2006) \\
\hline \multirow[t]{2}{*}{$\begin{array}{l}\text { Blended } \\
\text { Learning (10) }\end{array}$} & Videostreaming (4) & $\begin{array}{l}\text { (Beyth-Marom et al. 2005),(Seidel Tina } \\
\text { 2011), (Abdous et al. 2010; Ermeling } \\
\text { 2010) }\end{array}$ \\
\hline & CBT (6) & $\begin{array}{l}\text { (Shanley et al. 2004),(Fransen et al. } \\
\text { 2011),(Kirschner et al. 2009), (McDonald } \\
\text { 2004; Rasch et al. 2009) (Greene et al. } \\
\text { 2010) }\end{array}$ \\
\hline M-Learning (1) & Mobile Devices (1) & $(\operatorname{Kim} 2005)$ \\
\hline
\end{tabular}

Table 2: Classification of IT -tools

\section{Validation of Multidimensional Constructs}

Most of the empirical studies tested the influence of one or more input factors on one or more throughput and output factors. Since the productivity concept enables a categorization of the identified links, study designs could be visualized. Therefore, we categorized all the identified input, throughput and output factors in the framework of the productivity concept. This was conducted independently by two researchers familiar with the concept and the studies at hand. Subsequently, all the results were compared and unclear categories were discussed and clarified.

For reasons of understandability, we focused on studies which included IT tools. The link with the strongest empirical support is the learning methods and service quality, i.e. the lecturers' performance, respectively the effects of IT tools on learning methods and service quality. 


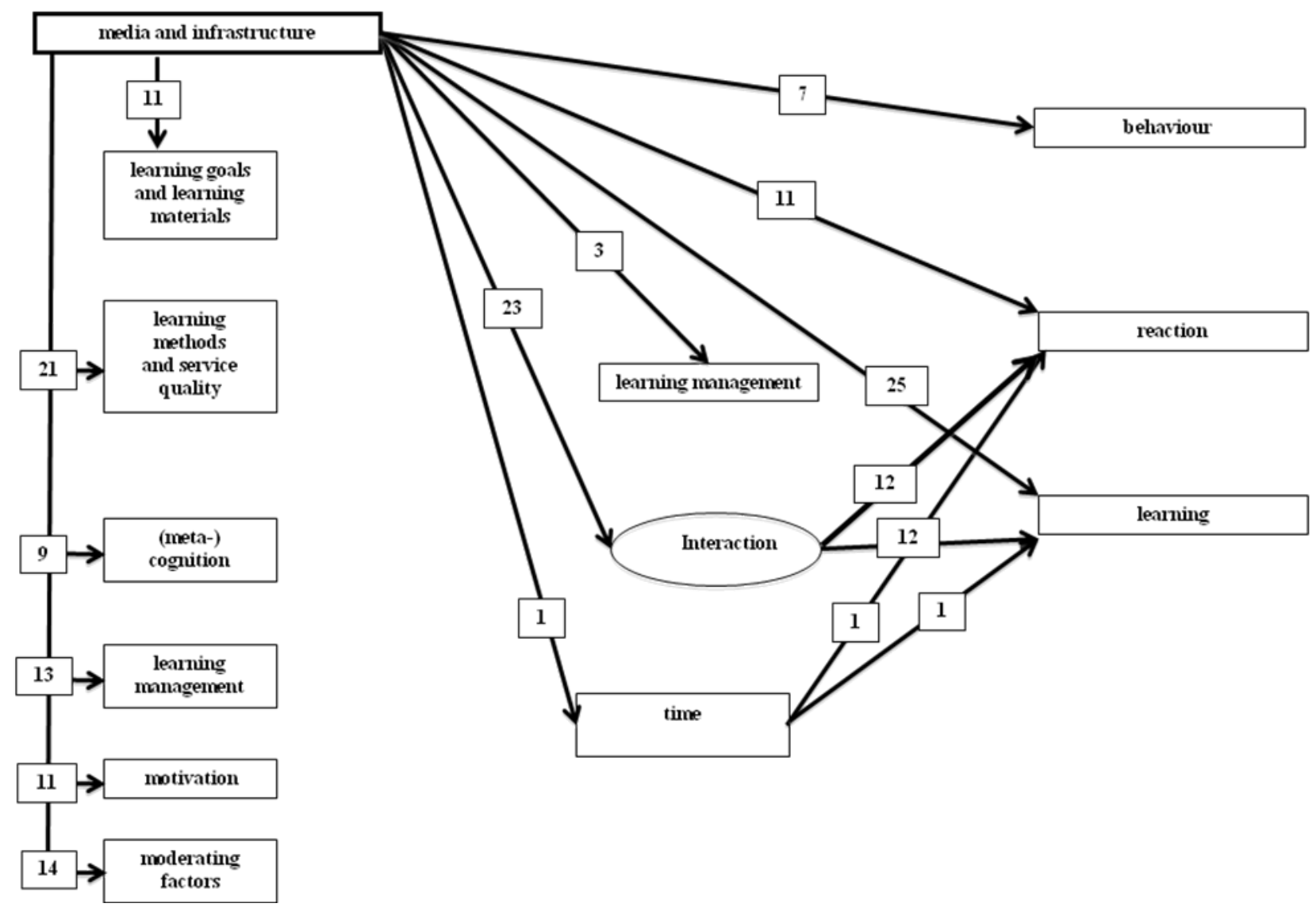

Figure 3: Dimensions of TML Evaluation

\section{CONCLUSION}

\section{Summary of the Findings}

This article presents the result of a literature review to examine the state-of-the-art of the measurement of (technologymediated) learning services. A total of 91 studies was collected, analyzed and presented.

Based on an in-depth analysis of the 91 studies, we could identify the following findings:

- We could not identify a pivotal theoretical foundation in any of the articles; The most common way of developing a measurement model was the undertaking of a literature review which analyzed a similar problem and the derivation of a modified model.

- More than $2 / 3$ of the studies used a quantitative research design to evaluate learning services. The results of our literature review indicate that the most common study design was the evaluation of a certain measure that students / employees support by means of surveys and a structural equation modeling.

- More than $70 \%$ of the studies considered the lecturers performance in their research. Thereby, a statistically significant influence of the lecturers' proficiency could be shown.

- The comparison between traditional and technology-mediated learning indicates that traditional learning studies focus often solely on one or two input factors and rarely on process dimensions. Technology-mediated learning studies more often take process variables into consideration, emphasizing the function of IT as a process support tool. 
- The most common object of investigation within the learning process was the interaction between students, followed by the interaction between students and lecturers. The process factor time was only considered once, which is especially interesting from a business perspective since time is highly relevant in terms of effort.

- Although there are many theoretical models for the measurement and evaluation of technology-mediated learning, a broad variety of models is used, depending on the discipline and its research focus.

- We identified no systematic way of evaluation. Findings always remained within the limits of the specific area and the special circumstances of the individual study. This holds especially true for IT- tools, which can be designed in very different ways although they might carry the same name, making it hard to add to existing knowledge base.

\section{Limitations}

The review is based on a limited number of journals from not more than five data-bases. Although major contributions to the field are likely to be found in leading journals, the scope may be problematic, since various disciplines were in the focus of the study. Hence, important articles may have been overlooked. Finally, the analysis and classification of the publications were based on the assessment of two researchers, conducting research in the same area and having similar backgrounds. Hence, a double-check conducted by an independent researcher could have helped to increase the quality of the results.

\section{Recommendations for Future Research}

The literature review presented a classification of research input, throughput and output factors. Based on these results, the following suggestions for further research can be made:

- King and He (2005) found a sampling bias in literature reviews towards quantitative empirical studies. However, we considered non-empirical studies, but with a main focus on literature reviews. Therefore the consideration of nonempirical studies, such as frameworks or conceptual works should be considered.

- The inclusion of the learning process perspective in a systematic way is recommendable, in order to get comparable results and to extend the research on the potential use of technology in the context of learning services (Gupta et al. 2009). The review showed that there is a lack of systematic research on process variables and causal effects.

- To make learning service evaluations comparable, a systematic evaluation approach should be identified, depending on the specific research agenda and existing results in that area.

- A review of and characterization of theoretical models feasible for the evaluation of learning services would support researchers in finding adequate models for research design. Furthermore, a standardized approach would help to achieve comparable results.

\section{*full analysis sheet available upon request}




\section{REFERENCES}

1. Abdous, M.h., and Yoshimura, M. "Learner outcomes and satisfaction: A comparison of live video-streamed instruction, satellite broadcast instruction, and face-to-face instruction," Computers \&amp; Education (55:2) 2010, pp 733-741.

2. Aggarwal, A.K., and Adlakha, V.G. "Quality management applied to web-based courses," Total Quality Management \& Business Excellence (17:1), 2006/01/01 2006, pp 1-19.

3. Alavi, M., and Leidner, D.E. "Review: Knowledge management and knowledge management systems: Conceptual foundations and research issues," MIS quarterly) 2001, pp 107-136.

4. Aleahmad, T., Aleven, V., and Kraut, R. "Creating a Corpus of Targeted Learning Resources with a Web-Based Open Authoring Tool," Learning Technologies, IEEE Transactions on (2:1) 2009, pp 3-9.

5. Appleton, L. "LolliPop for learning resources: Information literacy staff training within further education," Journal of Librarianship and Information Science (42:3) 2010, p 191.

6. Arbaugh, J. "How classroom environment and student engagement affect learning in Internet-based MBA courses," Business Communication Quarterly (63:4) 2000a, p 9.

7. Arbaugh, J., and Duray, R. "Technological and structural characteristics, student learning and satisfaction with webbased courses," Management Learning (33:3) 2002, pp 331-347.

8. Arbaugh, J., and Rau, B.L. "A study of disciplinary, structural, and behavioral effects on course outcomes in online MBA courses," Decision Sciences Journal of Innovative Education (5:1) 2007, pp 65-95.

9. Arbaugh, J.B. "Virtual Classroom Characteristics and Student Satisfaction with Internet-Based MBA Courses," Journal of Management Education (24:1), February 1, 2000 2000b, pp 32-54.

10. Arbaugh, J.B. "Virtual Classroom versus Physical Classroom: An Exploratory Study of Class Discussion Patterns and Student Learning in an Asynchronous Internet-Based MBA Course," Journal of Management Education (24:2) 2000c, pp 213-233.

11. Arbaugh, J.B. "How Instructor Immediacy Behaviors Affect Student Satisfaction and Learning in Web-Based Courses," Business Communication Quarterly (64:4), December 1, 2001 2001, pp 42-54.

12. Arthur Jr, W., Bennett Jr, W., Edens, P.S., and Bell, S.T. "Effectiveness of training in organizations: A meta-analysis of design and evaluation features," Journal of Applied Psychology (88:2) 2003, p 234.

13. Austin, K.A. "Multimedia learning: Cognitive individual differences and display design techniques predict transfer learning with multimedia learning modules," Computers \& Education (53:4) 2009, pp 1339-1354.

14. Baker, J.D. "An investigation of relationships among instructor immediacy and affective and cognitive learning in the online classroom," The Internet and Higher Education (7:1) 2004, pp 1-13.

15. Benbunan-Fich, R., and Arbaugh, J.B. "Separating the effects of knowledge construction and group collaboration in learning outcomes of web-based courses," Inf. Manage. (43:6) 2006, pp 778-793.

16. Beyth-Marom, R., Saporta, K., and Caspi, A. "Synchronous vs. Asynchronous Tutorials: Factors Affecting Students' Preferences and Choices," Journal of Research on Technology in Education (37:3) 2005, pp 245-262.

17. Bitzer, P., Bittner, E.A., and Leimeister, J.M. Identifying a set of relevant input and output factors for a knowledge intensive service within a productivity model for educational services, Hamburg, Germany 2011.

18. Bitzer, P., Wegener, R., and Leimeister, J.M. Entwicklung eines Produktivitätsmodells zur Systematisierung von Lerndienstleistungen, Leipzig, Germany, 2010.

19. BMWI "11. Faktenbericht 2008," 2008.

20. Bolliger, D.U., Supanakorn, S., and Boggs, C. "Impact of podcasting on student motivation in the online learning environment," Computers \& Education (55:2) 2010, pp 714-722.

21. Bower, M., and Hedberg, J.G. "A quantitative multimodal discourse analysis of teaching and learning in a webconferencing environment-The efficacy of student-centred learning designs," Computers \& Education (54:2) 2010, pp 462-478.

22. Cheng, Y.M., Chen, L.S., Huang, H.C., Weng, S.F., Chen, Y.G., and Lin, C.H. "Building a general purpose pedagogical agent in a web-based multimedia clinical simulation system for medical education," Learning Technologies, IEEE Transactions on (2:3) 2009, pp 216-225.

23. Chou, C. "Incidences and correlates of Internet anxiety among high school teachers in Taiwan," Computers in Human Behavior (19:6) 2003, pp 731-749.

24. Delone, W.H., and McLean, E.R. "The DeLone and McLean model of information systems success: A ten-year update," Journal of management information systems (19:4) 2003, pp 9-30.

25. DiMaggio, P., Hargittai, E., Neuman, W.R., and Robinson, J.P. "Social implications of the Internet," Annual review of sociology) 2001, pp 307-336.

26. Edmonds, C.T., and Edmonds, T.P. "An empirical investigation of the effects of SRS technology on introductory managerial accounting students," Issues in Accounting Education (23:3) 2008, pp 421-434. 
27. Ermeling, B.A. "Tracing the effects of teacher inquiry on classroom practice," Teaching and Teacher Education (26:3) 2010, pp 377-388.

28. Fettke, P. "State-of-the-Art des State-of-the-Art," Wirtschaftsinformatik (48:4) 2006, pp 257-266.

29. Fransen, J., Kirschner, P.A., and Erkens, G. "Mediating team effectiveness in the context of collaborative learning: The importance of team and task awareness," Comput. Hum. Behav. (27:3) 2011, pp 1103-1113.

30. Friday, E., Friday-Stroud, S.S., Green, A.L., and Hill, A.Y. "A multi-semester comparison of student performance between multiple traditional and online sections of two management courses," Journal of Behavioral and Applied Management (8:1) 2006, pp 66-81.

31. Garrison, D.R., and Kanuka, H. "Blended learning: Uncovering its transformative potential in higher education," The Internet and Higher Education (7:2) 2004, pp 95-105.

32. Graham, P. "Improving Teacher Effectiveness through Structured Collaboration: A Case Study of a Professional Learning Community," RMLE Online: Research in Middle Level Education (31:1) 2007, pp 1-17.

33. Greene, J.A., Costa, L.-J., Robertson, J., Pan, Y., and Deekens, V.M. "Exploring relations among college students' prior knowledge, implicit theories of intelligence, and self-regulated learning in a hypermedia environment," Computers \&amp; Education (55:3) 2010, pp 1027-1043.

34. Grönroos, C., and Ojasalo, K. "Service productivity: Towards a conceptualization of the transformation of inputs into economic results in services," Journal of Business Research (57:4) 2004, pp 414-423.

35. Gupta, S., and Bostrom, R.P. "Technology-Mediated Learning: A Comprehensive Theoretical Model," Journal of the Association for Information Systems (10:9) 2009, pp 686-714.

36. Gupta, S., Bostrom, R.P., and Huber, M. "End-user training methods: what we know, need to know," ACM SIGMIS Database (41:4) 2008, pp 9-39.

37. Hansen, D.E. "Knowledge transfer in online learning environments," Journal of Marketing Education (30:2) 2008, pp 93-105.

38. Hornik, S., Saunders, C.S., Li, Y., Moskal, P.D., and Dzuiban, C.D. "The impact of paradigm development and course level on performance in technology-mediated learning environments," Informing Science: International Journal of an Emerging Transdiscipline (11) 2008, pp 35-58.

39. Hui, W., Hu, P.J.H., Clark, T., Tam, K., and Milton, J. "Technology-assisted learning: a longitudinal field study of knowledge category, learning effectiveness and satisfaction in language learning," Journal of Computer Assisted Learning (24:3) 2008, pp 245-259.

40. Johnson, R.D., Gueutal, H., and Falbe, C.M. "Technology, trainees, metacognitive activity and e-learning effectiveness," Journal of managerial psychology (24:6) 2009, pp 545-566.

41. Joiner, R. "Supporting collaboration in virtual learning environments," CyberPsychology \& Behavior (7:2) 2004, pp 197200.

42. Jui-Feng, W., Shian-Shyong, T., and Tsung-Ju, L. "Teaching Boolean Logic through Game Rule Tuning," Learning Technologies, IEEE Transactions on (3:4) 2010, pp 319-328.

43. Kim, G.-M.O., Soo Min "AN EXPLORATORY STUDY OF FACTORS INFLUENCING M-LEARNING SUCCESS," Journal of Computer Information Systems (46:1) 2005, pp 92-97.

44. King, W.R., and He, J. "Understanding the role and methods of meta-analysis in IS research," Communications of the Association for Information Systems (16:1) 2005, pp 665-686.

45. Kirkpatrick, D.L., and Kirkpatrick, J.D. Transferring learning to behavior: Using the four levels to improve performance Berrett-Koehler, 2005.

46. Kirschner, F., Paas, F., and Kirschner, P.A. "Individual and group-based learning from complex cognitive tasks: Effects on retention and transfer efficiency," Comput. Hum. Behav. (25:2) 2009, pp 306-314.

47. Leimeister, J.M. Dienstleistungsengineering und -management Springer Gabler, Berlin, 2012.

48. Lemak, D.J., Shin, S.J., Reed, R., and Montgomery, J.C. "Technology, transactional distance, and instructor effectiveness: An empirical investigation," Academy of Management Learning \& Education) 2005, pp 150-159.

49. Li, Y., Harrison, L., Aidong, L., Zhiwei, L., and Weichao, W. "3D Digital Legos for Teaching Security Protocols," Learning Technologies, IEEE Transactions on (4:2) 2011, pp 125-137.

50. Lin, H.F. "Measuring online learning systems success: Applying the updated DeLone and McLean model," CyberPsychology \& Behavior (10:6) 2007, pp 817-820.

51. Marks, R.B., Sibley, S.D., and Arbaugh, J. "A structural equation model of predictors for effective online learning," Journal of Management Education (29:4) 2005, pp 531-563.

52. MBB "Weiterbildung und Digitales Lernen heute und in drei Jahren: Mobile und vernetzte Szenarien im Aufwind,") 2011.

53. McDonald, D.S. "The influence of multimedia training on users' attitudes: lessons learned," Computers \& Education (42:2) 2004, pp 195-214. 
54. Nabil, L. "An Online RFID Laboratory Learning Environment," IEEE Transactions on Learning Technologies (2) 2009, pp 295-303.

55. Ozkan, S., and Koseler, R. "Multi-dimensional students' evaluation of e-learning systems in the higher education context: An empirical investigation," Computers \& Education (53:4) 2009, pp 1285-1296.

56. Piccoli, G., Ahmad, R., and Ives, B. "Web-Based Virtual Learning Environments: A Research Framework and a Preliminary Assessment of Effectiveness in Basic IT Skills Training," MIS Quarterly (25:4) 2001, pp 401-426.

57. Qiyun, W. "Using online shared workspaces to support group collaborative learning," Computers \&amp; Education (55:3) 2010, pp 1270-1276.

58. Rasch, T., and Schnotz, W. "Interactive and non-interactive pictures in multimedia learning environments: Effects on learning outcomes and learning efficiency," Learning and Instruction (19:5) 2009, pp 411-422.

59. Rossett, A. "Waking in the night and thinking about e-learning," The ASTD e-learning handbook) 2002, pp 3-18.

60. Salleh, N., Mendes, E., and Grundy, J. "Empirical studies of pair programming for CS/SE teaching in higher education: A systematic literature review," Software Engineering, IEEE Transactions on:99) 2011, pp 1-1.

61. Sasidharan, S., and Santhanam, R. "Technology-based training," Human-computer interaction and management information systems: applications (6) 2006, p 247.

62. Seidel Tina, S.K., Blomberg Geraldine, Kobarg Mareike, Schwindt Katharina "Teacher Learning from Analysis of Videotaped Classroom Situations: Does It Make a Difference whether Teachers Observe their own Teaching or that of Others?," Teaching and Teacher Education (27:2) 2011, pp 259-267.

63. Shanley, E.L., Thompson, C.A., Leuchner, L.A., and Zhao, Y. "Distance education is as effective as traditional education when teaching food safety§," Food Service Technology (4:1) 2004, pp 1-8.

64. Sousa, N., Alves, G.R., and Gericota, M.G. "An Integrated Reusable Remote Laboratory to Complement Electronics Teaching," Learning Technologies, IEEE Transactions on (3:3) 2010, pp 265-271.

65. Strother, J.B. "An assessment of the effectiveness of e-learning in corporate training programs," The International Review of Research in Open and Distance Learning (3:1) 2002, p Article 3.1. 2.

66. Tao, Y.H., Ho, I., and Yeh, R.C. "Building a user-based model for web executive learning systems--a study of Taiwan's medium manufacturing companies," Computers \& Education (36:4) 2001, pp 317-332.

67. Webster, J.W., R.T., "ANALYZING THE PAST TO PREPARE R THE FUTURE: WRITING A," MIS quarterly (26:2) 2002.

68. Williams, E.A., Duray, R., and Reddy, V. "Teamwork orientation, group cohesiveness, and student learning: A study of the use of teams in online distance education," Journal of Management Education (30:4) 2006, pp 592-616.

69. Zhang, D., Zhou, L., Briggs, R.O., and Jay F. Nunamaker, J. "Instructional video in e-learning: assessing the impact of interactive video on learning effectiveness," Inf. Manage. (43:1) 2006, pp 15-27. 